\title{
Pengaruh Umur Induk dan Lama Penyimpanan Telur terhadap Bobot Telur, Daya Tetas dan Bobot Tetas Ayam Kedu Jengger Merah
}

\author{
The Effect of Hen Age and Storage Duration on Egg Weight, Hatchability and Hatching \\ Weight of Red Comb Kedu Chicken
}

\author{
R. Sumbayak*, E. Kurnianto dan S. Kismiati \\ Faculty of Animal and Agricultural Sciences, Diponegoro University, \\ Tembalang Campus, Semarang 50275 - Indonesia \\ *Corresponding E-mail : sumbayakrico@gmail.com
}

\begin{abstract}
The objective of this research was to evaluate the effect of parent age and egg storage duration on the weight of hatching eggs, hatchability, and weight of hatchings of red comb Kedu chicken. The materials used in the study were 121 eggs producedly 25 females and 5 males from red comb Kedu chicken aged 61-65 weeks, with a sex ratio of 1: 5 . The research design used was a completely randomized design (CRD) factorial pattern $5 \times 4$ with five replications. The first factor was the hen age $(61,62,63,64$ dan 65 weeks) and the second factor was storage duration for hatching egg $(1,3,5$ and 7 days) at room temperature. The parameters observed were egg weight, hatchability, and hatching weight. The data obtained were analyzedly using the General Linear Model (GLM) procedure with SAS Ver. 6.12. The results showed that the hen age and storage duration did not show significant interaction with the parameters observed. Hen age did not affect the parameters observed however the storage duration had significant effect $(\mathrm{P}<0.05)$ on hatchability, but had no effect on the egg weight and hatching weight. In conclusion, hatchability was decreased at the storage duration of 7 day.
\end{abstract}

Key words : Kedu chicken, storage duration, hen age, egg weight, hatchability, hatching weight

\begin{abstract}
ABSTRAK
Penelitian ini bertujuan untuk mengetahui pengaruh umur induk dan lama penyimpanan telur terhadap bobot telur tetas, daya tetas, dan bobot tetas ayam Kedu Jengger Merah. Materi yang digunakan dalam penelitian adalah 121 butir telur hasil produksi 25 ekor betina dan 5 ekor jantan Ayam Kedu Jengger Merah umur 61-65 minggu, dengan sex ratio $1: 5$. Rancangan penelitian yang digunakan adalah rancangan acak lengkap (RAL) pola faktorial 5 x 4 dengan 5 kali ulangan. Faktor pertama adalah umur induk $(61,62,63$, 64 dan 65 minggu) dan faktor kedua adalah lama penyimpanan telur tetas (1,3,5 dan 7 hari) pada suhu ruang. Parameter yang diamati adalah bobot telur tetas, daya tetas, dan bobot tetas. Data yang diperoleh dianalisis menggunakan prosedur General Linear Model (GLM) dengan alat bantu SAS Ver. 6.12. Hasil penelitian menunjukkan bahwa tidak terdapat pengaruh interaksi antara umur induk dan lama simpan terhadap parameter yang diamati. Umur induk tidak berpengaruh nyata terhadap parameter yang diamati sedangkan lama simpan berpengaruh nyata $(\mathrm{P}<0,05)$ terhadap daya tetas, tetapi tidak berpengaruh nyata terhadap bobot telur dan bobot tetas. Kesimpulan adalah daya tetas menurun pada lama penyimpanan 7 hari.
\end{abstract}

Kata kunci : ayam Kedu, lama penyimpanan, umur induk, bobot telur tetas, daya tetas, bobot tetas

\section{PENDAHULUAN}

Ayam Kedu merupakan salah satu jenis ayam lokal Indonesia tipe dwiguna yang produktivitasnya cukup tinggi dan masih banyak dipelihara oleh kalangan masayarakat di daerah Kedu, Kabupaten Temanggung, Jawa Tengah. Ayam Kedu memiliki beberapa karakteristik warna antara lain kedu hitam, kedu putih, kedu merah, dan kedu cemani (Rukmana, 2003). Ayam Kedu memiliki daya tahan tubuh yang cukup tinggi, sehingga tidak mudah terserang penyakit serta memiliki komposisi daging yang padat (Johari et al., 2009).

Perkembangan ayam kedu di kalangan masyarakat belum sepenuhnya murni. Populasi yang semakin rendah dan umur induk yang sudah tua dapat mengakibatkan kepunahan, sehingga perlu dilakukan proses pemurnian untuk menghasilkan galur murni dan mencegah kepunahan tersebut. Pengembangan usaha ayam kedu dapat dilakukan dengan berbagai cara salah satunya adalah melakukan penetasan. Keberhasilan penetasan dipengaruhi oleh kulitas 
telur. Salah satu faktor yang mempengaruhi kualitas telur adalah umur induk dan lama penyimpanan.

Kondisi umur induk dan proses penanganan telur sebelum penetasan yang sering diabaikan oleh peternak sangat berpengaruh terhadap keberhasilan penetasan. Umur yang sudah tua mengakibatkan produksi berkurang, kerabang menipis dan bobot telur yang semakin besar (Widiatmoko at al., 2014). Informasi tentang pengaruh umur induk dan lama penyimpanan telur terhadap bobot telur tetas, daya tetas, dan bobot tetas ayam kedu belum banyak diketahui sehingga perlu ditelusuri pengaruh umur induk dan lama penyimpanan telur terhadap bobot telur tetas, daya tetas, dan bobot tetas pada ayam kedu. Penelitian ini bertujuan untuk mengetahui pengaruh umur induk dan lama penyimpanan telur terhadap bobot telur tetas, daya tetas, dan bobot tetas Ayam Kedu Jengger Merah.

\section{MATERI DAN METODE}

Penelitian ini dilaksanakan pada bulan September - November 2018 di Balai Pusat Bibit Ternak Non Ruminansia (BPBTNR) Satker Ayam Maron, Jl. Kadar, Ds. Sidorejo, Kec. Temanggung, Kab. Temanggung. Materi yang digunakan dalam penelitian adalah Ayam Kedu Jengger Merah 5 ekor Jantan dan 25 ekor betina umur 61-65 minggu yang dikelompokkan dalam 5 pen dengan sex ratio $1: 5$. Jumlah telur yang digunakan 121 butir disimpan pada suhu ruang dengan lama penyimpanan 1, 3, 5, 7 hari.

Peralatan yang digunakan adalah timbangan, egg candler, egg tray, jaring kecil, mesin tetas otomatis. Rancangan penelitian yang digunakan adalah rancangan acak lengkap (RAL) pola faktorial 5 x 4 dengan 5 kali ulangan. Faktor pertama adalah umur induk $(61,62,63,64$ dan 65 minggu) dan faktor kedua adalah lama penyimpanan telur tetas $(1,3,5$ dan 7 hari) pada suhu ruang. Parameter yang diamati adalah bobot telur tetas, daya tetas, dan bobot tetas. Rumus perhitungan (Pratiwi et al., 2013) sebagai berikut:

\section{Daya Tetas $=\left[\sum\right.$ telur menetas $/ \sum$ telur fertil ] x $100 \%$}

2. Bobot telur tetas = bobot yang ditimbang sebelum masuk kedalam mesin tetas

3. Bobot Tetas = Anak ayam (DOC) ditimbang.

Daya tetas ditransformasi menggunakan

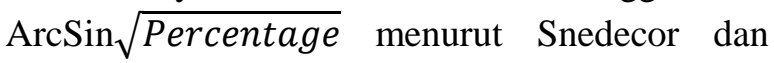
Cochran (1989). Data yang diperoleh dianalisis dengan menggunakan analisis ragam (Wahyono, 2009). Jika ada pengaruh perlakuan terhadap parameter dilanjutkan dengan uji jarak Duncan Multiple Range Test (DMRT).

\section{HASIL DAN PEMBAHASAN}

\section{Bobot Telur Tetas Ayam Kedu Jengger Merah}

Rataan bobot telur tetas Ayam Kedu Jengger Merah yang disimpan pada (1 , 3, 5 dan 7 hari) dan umur induk $(61,62,63,64$ dan 65 minggu) disajikan pada Tabel 1. Tabel 1 menunjukkan bahwa tidak terdapat pengaruh interaksi antara umur induk dengan lama simpan terhadap bobot telur tetas. Umur induk maupun lama simpan tidak berpengaruh nyata terhadap bobot telur tetas. Umur induk tidak berpengaruh nyata terhadap bobot telur tetas. Hal ini diduga karena umur induk yang digunakan hanya berjarak satu minggu. Penelitian Akyurek dan Okur (2009), menunjukkan bahwa induk dengan umur 22 minggu dan 50 minggu menyebabkan bobot telur meningkat secara nyata.

Tabel 1. Rataan bobot telur tetas ayam Kedu Jengger Merah

\begin{tabular}{ccccccc}
\hline \multirow{2}{*}{$\begin{array}{c}\text { Lama Simpan } \\
\text { (hari) }\end{array}$} & 61 & 62 & 63 & 64 & 65 & \multirow{2}{*}{ Rataan (g) } \\
\cline { 2 - 6 } & 48,84 & 49,63 & 48,23 & 45,28 & 48,69 & 48,09 \\
3 & 47,34 & 46,24 & 47,71 & 46,35 & 46,23 & 46,89 \\
5 & 47,39 & 45,78 & 45,36 & 44,83 & 45,43 & 45,98 \\
7 & 42,44 & 45,31 & 47,55 & 46,81 & 48,97 & 46,34 \\
Rataan (g) & 46,78 & 46,96 & 47,14 & 45,80 & 46,93 & \\
\hline
\end{tabular}


Lama simpan tidak berpengaruh nyata terhadap bobot telur tetas. Hal ini dipengaruhi oleh suhu penyimpanan telur sebelum penetasan yang digunakan berkisar pada suhu $20-25^{\circ} \mathrm{C}$. Hasil penelitian sesuai dengan Akyurek dan Okur (2009), bahwa penyimpanan telur hingga 9 hari pada suhu $20^{\circ} \mathrm{C}$ tidak berpengaruh nyata terhadap bobot telur tetas. Didukung oleh penelitian Wedana et al. (2017), bahwa telur ayam Ras yang disimpan pada $(0,7,14$ dan 21 hari) dengan suhu $25^{\circ} \mathrm{C}$ tidak berpengaruh nyata terhadap bobot telur.

\section{Daya Tetas Ayam Kedu Jengger Merah}

Rataan daya tetas Ayam Kedu Jengger Merah yang disimpan pada (1, 3, 5 dan 7 hari) dan umur induk (61, 62, 63, 64 dan 65 minggu) disajikan pada Tabel 2.

Tabel 2. Rataan daya tetas ayam Kedu Jengger Merah

\begin{tabular}{|c|c|c|c|c|c|c|}
\hline \multirow{2}{*}{$\begin{array}{l}\text { Lama Simpan } \\
\text { (hari) }\end{array}$} & \multicolumn{5}{|c|}{ Umur Induk (minggu) } & \multirow{2}{*}{ Rataan (\%) } \\
\hline & 61 & 62 & 63 & 64 & 65 & \\
\hline 1 & 100,00 & 81,25 & 83,33 & 86,66 & 100,00 & $89,35^{\mathrm{a}}$ \\
\hline 3 & 87,50 & 71,67 & 90,00 & 100,00 & 100,00 & $87,91^{\mathrm{ab}}$ \\
\hline 5 & 75,00 & 100,00 & 70,83 & 66,67 & 75,00 & $76,28^{\mathrm{bc}}$ \\
\hline 7 & 100,00 & 85,41 & 58,33 & 60,41 & 85,41 & $75,46^{\mathrm{c}}$ \\
\hline Rataan (\%) & 88,33 & 81,66 & 76,78 & 78,33 & 91,67 & \\
\hline
\end{tabular}

Keterangan : Superskrip yang berbeda pada kolom menunjukkan perbedaan yang nyata $(\mathrm{P}<0,05)$.

Tabel 2 menunjukkan bahwa tidak terdapat pengaruh interaksi antara umur induk dengan lama simpan terhadap daya tetas. Umur induk tidak berpengaruh nyata terhadap daya tetas, sedangkan lama simpan berpengaruh nyata $(\mathrm{P}<0,05)$ terhadap daya tetas. Umur induk tidak berpengaruh nyata terhadap daya tetas. Hal ini diduga karena umur induk yang digunakan hanya berjarak 1 minggu. Penelitian Widiatmoko et al. (2014), menunjukkan bahwa induk kalkun dengan umur 9 bulan, 11 bulan dan 13 bulan menyebabkan penurunan secara nyata terhadap daya tetas.

Daya tetas mulai menurun pada penyimanan 7 hari. Menurut penelitian Schmidt et al. (2009) penurunan daya tetas terjadi pada peyimpanan 3 hari. Hal tersebut terjadi karena masa simpan telur yang lama mengakibatkan pori-pori kerabang membesar sehingga mempermudah mikroorganisme masuk kedalam telur. Menurut Rasyaf (1991), telur yang disimpan jangka waktu lama dapat mengakibatkan pori-pori kerabang telur membesar dan mempermudah terkontaminasi mikroorganisme yang menyebabkan kualitas telur rendah, embrio mati dan daya tetas menurun.

\section{Bobot Tetas Ayam Kedu Jengger Merah}

Rataan bobot tetas Ayam Kedu Jengger Merah yang disimpan pada (1 , 3, 5 dan 7 hari) dan umur induk $(61,62,63,64$ dan 65 minggu) disajikan pada Tabel 3 .

Tabel 3 menunjukkan bahwa tidak terdapat pengaruh interaksi antara umur induk dengan lama simpan terhadap bobot tetas. Umur induk maupun lama simpan tidak berpengaruh nyata terhadap bobot tetas. Umur induk tidak berpengaruh nyata terhadap bobot tetas. Hal ini diduga karena umur yang digunakan hanya berjarak 1 minggu. Penelitian Tona et al. (2004), menunjukkan bahwa perbedaan umur induk 10 minggu yakni (35 dan 45 minggu) bobot tetas meningkat secara nyata.

Tabel 3. Rataan bobot tetas ayam Kedu Jengger Merah

\begin{tabular}{ccccccc}
\hline \multirow{2}{*}{$\begin{array}{c}\text { Lama Simpan } \\
\text { (hari) }\end{array}$} & 61 & 62 & 63 & 64 & 65 & \multirow{2}{*}{ Rataan (g) } \\
\cline { 2 - 5 } & 31,25 & 30,86 & 31,51 & 29,11 & 33,08 & 30,92 \\
3 & 31,18 & 31,14 & 31,35 & 29,98 & 30,75 & 30,97 \\
5 & 31,49 & 29,92 & 30,67 & 29,08 & 29,37 & 30,33 \\
7 & 28,15 & 30,29 & 31,14 & 30,99 & 32,15 & 30,65 \\
Rataan (g) & 30,62 & 30,64 & 31,06 & 29,77 & 30,99 & \\
\hline
\end{tabular}


Lama simpan tidak berpengaruh nyata terhadap bobot tetas. Hal ini disebebkan oleh bobot telur (Tabel 1.) tidak berbeda nyata. Kholis dan Sarwono (2013) menjelaskan bahwa bobot telur berkaitan dengan bobot tetas. Penelitian Khan et al. (2014) menunjukkan bahwa penurunan bobot tetas terjadi pada penyimpanan hari ke-2 dan ke-7. Didukung oleh penelitian Basha (2015), menunjukkan bahwa penyimpanan telur hingga 10 hari menurun secara nyata terhadap bobot tetas.

\section{KESIMPULAN}

Berdasarkan hasil penelitian disimpulkan bahwa umur induk tidak menyebabkan penurunan bobot telur tetas, daya tetas dan bobot tetas. Lama penyimpanan 7 hari menyebabkan daya tetas Ayam Kedu Jengger Merah menurun.

\section{DAFTAR PUSTAKA}

Akyurek, H. and A. A. Okur. 2009. Effect of storage duration, temperature and hen age on egg quality in free-range layer hens. J. Anim. Vet. Adv. 8 (10): 1953 - 1958.

Basha, H. A. 2015. Effect of storage period on egg weight loss, hatching weight and hatchability percentage of incubated egyptian balady eggs. J. Vet. Sci. 47:216 220.

Johari, S., Sutopo, A. Santi. 2009. Frekuensi enotipik sifat -sifat kuantitatif ayam Kedu dewasa. Seminar Nasional Kebangkitan Peternakan. Semarang. 20 Mei 2009. Hal 606-616.

Khan, M. J. A., S. H. Khan, A. Bukhsh and M. Amin. 2014. The effect of storage duration on egg quality and hatchability characteristic of Rhode Island Red (RIR) hens. J. Vet. Arhiv. 84 (3):291 - 303.

Kholis, S. dan B. Sarwono. 2013. Ayam Elba, Kampung Petelur Super. Penebar Swadaya, Jakarta.
Pratiwi, R. N., H. I. Wahyuni, dan W. Murningsih. 2013. Pengaruh Pemberian Vitamin A dan E Dalam Ransum Terhadap Daya Tunas, Daya Tetas, Bobot Tetas dan Daya Hidup DOC Ayam Kedu Hitam yang Dipelihara In Situ. Animal Agriculture Journal 2 (1), 240-246.

Rasyaf, M. 1991. Pengelolaan Produksi Telur. Kanisius. Yogyakarta

Rukmana, H. R. 2003. Ayam Buras Intensifikasi dan kiat Pengembangan. Kanisius. Yogyakarta

Schmidt, G. S., E. A. P. Figueiredo, M. G. Saarkamp dan E. R. Bomm. 2009. Effect of storage period and egg weight on embryo development and incubation result. Brazilian Journal of Poultry Science. 11(1): $01-05$.

Snedecor, G. W. Dan W. G. Cochran. 1989. Statistical. 1st Ed., University o Rryukyus, Nishihara-cho, Okinawa, Japan.

Tona, K., O. Onagbesan, B. D. Ketelaere, E. Decuypere and V. Bruggemen. 2004. Effect of age of broiler breeders on egg quality, hatchability, chick quality, chick weight, and chick posthatch growth to forty-two days. J. Appl. Poult. Res. 13 (1): $10-18$.

Wahyono, T. 2009. Model Analisis Statistik. PT. Elex Media Komputindo. Jakarta.

Wedana, I. P. C., I. K. A. Wiyana dan M. Wirapartha. 2017. Pengaruh lama penyimpanan terhadap kualitas fisik telur ayam ras yang dipelihara secara intensif. J. Peternakan Tropika. 5 (1):1 - 10.

Widiatmoko, F., T. Kurtini dan L. Nova. 2014. Pengaruh umur induk terhadap fertilitas, susut tetas, daya tetas, dan bobot tetas telur kalkun. J. Ilmiah Petrnakan Terpadu 2 (1): $19-25$. 